\title{
PERCEPTIONS OF GREEN AND SMART URBAN TRANSPORT ISSUES IN ROMANIAN CITIES: A PRELIMINARY EXPLORATORY ANALYSIS
}

\author{
Alexandru BĂNICĂ \\ Alexandru Ioan Cuza University, lași, Faculty of Geography and Geology, ROMANIA \\ Romanian Academy - Iași Branch, Geography Group, ROMANIA \\ alexandru.banica@uaic.ro \\ Mihail EVA \\ Alexandru Ioan Cuza University, Iași, Faculty of Geography and Geology, ROMANIA \\ mihail.i.eva@gmail.com \\ Corneliu IAȚ \\ Alexandru Ioan Cuza University, Iași, Faculty of Geography and Geology, ROMANIA \\ corneliu_iatu@yahoo.fr \\ DOI: http://doi.org/10.23740/TID220194
}

\section{ABSTRACT}

Urban transport is one of the most unsustainable activities in Romanian cities. Green and smart mobility solutions could help them in becoming more sustainable. However, it is generally acknowledged that successfully implementing green, smart and sustainable solutions depends highly on local stakeholders' engagement and public acceptance. Against this background, the current study explores stakeholders' perception and media coverage of some urban transport issues in Romanian cities. Our approach is only exploratory as it is not aimed at testing hypothesis, but rather at 1) exploring stakeholders' opinions concerning the state of urban mobility in Bucharest, lași and Cluj-Napoca, and at 2) identifying the main urban transport issues reflected in local newspapers from lași and Cluj-Napoca. Results concerning stakeholders' opinions suggest, inter alia, an overwhelming influence of local authorities and transport engineers in the decision-making process, a fact that is contrary to sustainable and good governance practices. Urban transport issues reflected in local newspapers pinpoint the high importance of public transport in Romanian postsocialist cities, a rather incipient emergence of green and smart practices, and some significant differences in the propensity of inquired cities to modernise their urban transport services.

Keywords: sustainable urban mobility, stakeholders' perceptions, tag cloud, local newspapers, survey

Cite this article as: Bănică, Al, Eva, M. \& laţu, C. (2019). Perceptions of Green and Smart Urban Transport Issues in Romanian Cities: A Preliminary Exploratory Analysis. Territorial Identity and Development, 4(2), 58-75. DOI: http://doi.org/10.23740/TID220194

\section{INTRODUCTION}

During the last decades, the sustainability of cities has been in the centre of urban policies, as a need to balance urban development and environmental protection (Hiremath et al., 2013). In this endeavour, the transformation of transport into a sustainable practice is a key challenge that is recognized as part of the Sustainable Development Goals (SDG) adopted by United Nations Member States in 2015. The contribution of transport is acknowledged to be essential and explicitly implied by SDG target 11.2: "By 2030, provide access to safe, affordable, accessible and sustainable transport systems for all, improving road safety, notably by expanding public 
transport, with special attention to the needs of those in vulnerable situations, women, children, persons with disabilities and older persons" (World Bank Group, 2016, p. 43).

To attain this target, cities should be capable of engaging various stakeholders in the innovation process on a very broad range of activities, fostering a governance system centred on citizens, but also aiming to put into place sound ecosystems that will produce valuable (but unquantifiable) services (Bria, 2012; Angelidou, 2014). The United Nations highlighted this idea during the Habitat III conference in Quito 2016. Promoting smart cities as a new paradigm for development is also a rather new policy direction that could support the transition towards more sustainable and resilient urban areas (UN-Habitat, 2016, p. 45). Meanwhile, the EU Transport Policy has also explicitly stated that transport sector should be integrated in the future clean, digital and modern economy, and, therefore, a comprehensive and updated strategy for sustainable and smart mobility is needed (EC, 2019). Therefore, urban policies now aim not only at attaining sustainability but also at encouraging smart mobility, which may (or may not) overlap with sustainability goals.

The challenge now relies on putting into place such visions. From a broad perspective, two main approaches have been implemented so far (Sultana et al., 2019): one that is based in managing the offer of transport services (heavily relying on technological innovations) and one that targets the management of the demand (heavily relying on changing social behaviour towards more sustainable practices). It is now acknowledged that policies aiming at managing the offer have not succeeded in tackling unsustainable transport activities (Chapman, 2007; Sultana et al., 2019). This is due mainly to the fact that technological improvements in reducing energy consumptions and pollution have been offset by increasing demand.

On the other hand, implementing policies aiming at changing social behaviour is much more challenging for at least two reasons. First, the implication of different stakeholders is essential in order to have clear and coherent results. Urban mobility experts and experienced practitioners can contribute with their knowledge to the development and implementation of innovative mobility solutions such as smart infrastructure, autonomous vehicles, and vehicle sharing that could urgently and radically transform the urban transport landscape (Ruprecht Consult, 2019). Second, sustainable, smart, and green solutions must be largely accepted by the population in order to become a day-to-day practice. Against this background, the current paper first surveys the local stakeholders' opinions concerning the state of urban mobility in a post-socialist urban context (taking as case studies Bucharest, lași and Cluj-Napoca). In the second part, it explores the main urban transport issues reflected in local newspapers from lași and Cluj-Napoca.

\section{THEORETICAL BACKGROUND}

The complementarity and interconnectedness, but also the competition between smart and sustainable cities are being debated as the goals declared by smart cities promoters are similar to those proposed in sustainable urban development strategies. However, in recent years, one can see that an increasing number of cities have shifted from sustainability approaches, that are found to be too general, towards smart targets (Marsal-Llacuna, Colomer-Llinàs \& MeléndezFrigola, 2015). Nevertheless, the approaches are far from completely overlapping. Numerous smart city strategies lack an explicit environmental dimension while predominantly highlighting social and economic issues (Ahvenniemi et al., 2017). Moreover, scholars define smart cities in 
many ways (Albino, Berardi \& Dangelico, 2015) and only some definitions reflect an obvious relationship with the sustainability targets and goals.

Generally, smart cities strategically capitalize on the Information and Communications Technology (ICT) developments, seeking to achieve wellbeing, to increase effectiveness and competitiveness on multiple social-economic scales. Smart cities integrate not only products but also services (i.e. platforms and applications), that need smaller investments and are also very adaptable to changing societal needs (Angelidou, 2014). Using ICT can make communities more interconnected while their urban habitat can become more comfortable, attractive and safe (Lazaroiu \& Roscia, 2012).

In this regard, smart cities have knowledge-intensive and innovative strategies able to increase the socio-economic, logistic and ecological performance and competitiveness of cities (Kourtit \& Nijkamp, 2012).

To a certain degree, there is an overlap and even a cross-fertilization between the two concepts as smart cities aim also at being greener and green cities imply the resource efficiency and the clean technologies promoted by smart mobility approaches (De Jong et al., 2015).

Another critique that is being addressed to smart city approaches is that they emerge from a certain ideological background of 'green technology', 'universal infrastructure' and 'ubiquitous computing' and aim to put into an advantage and to enlarge new technologies market with no consideration towards their wider social and environmental impacts (Viitanen \& Kingston, 2014). Moreover, smart technologies would create advantages for the private firms that produce or commercialize the infrastructure while marginalizing the social categories that do not possess the skills or do not want, by any reason, to use these edge technologies (Colding \& Barthel, 2017). Plus, using certain technologies such as virtual spaces could change social interactions which transform spatial and temporal linkage creating a "non-place urban realm" (Carmona et al., 2010). This implies a change not just of urban realities, but also of their perception, which, finally, results in changing urban identities.

Technological innovation is generally aiming at integrating the development of infrastructure and buildings with a certain physical design, advanced technologies, modern amenities and other best practices of urban planning (Pentikousis et al., 2011; Angelidou, 2014). Nevertheless, the replication of certain technological solutions can be risky. One solution will not suit for all cities. Meanwhile, technological innovation should also be socially accepted (Figure 1).

Integrating technological innovation in social behaviour is based on the need of collaboration among private actors and population and the engagement of the public, to design more liveable, sustainable, and smart cities (Sassen, 2011). This is the reason why bottom-up approaches would accelerate the innovation process. Moreover, it is stated in the literature that demand-driven approaches ware preferred by the most successful smart cities rather than supply-driven strategies (Angelidou, 2015).

As a consequence, the users-profile approach of technology is needed: technology should be responsive to individual needs and diverse skills and interests of users (Bria, 2012; Roche et al., 2012; Angelidou, 2015), but also "environmentally friendly" in itself. Therefore, the acceptance of new technologies and their actual impact on greening the cities should be assessed.

By integrating the two emerging city planning directions, Smart Green Cities (SGC) is a concept that was included in urban development models based on the utilization of social and technological capital for more developed and prosperous urban agglomerations (Angelidou, 2014). Consequently, the European Commission's "smart city" relies on green mobility that 
implies, inter alia, energy efficiency and the use of renewable forms of energy for the large urban areas (ESC, 2012). It is a response to some major social and environmental issues the cities confront with: increasing energy use and emissions, barrier effects of transport infrastructure, traffic congestion, noise and accidents, the expansion of transport infrastructure replacing green areas or existing built environments (Næss \& Vogel, 2012).

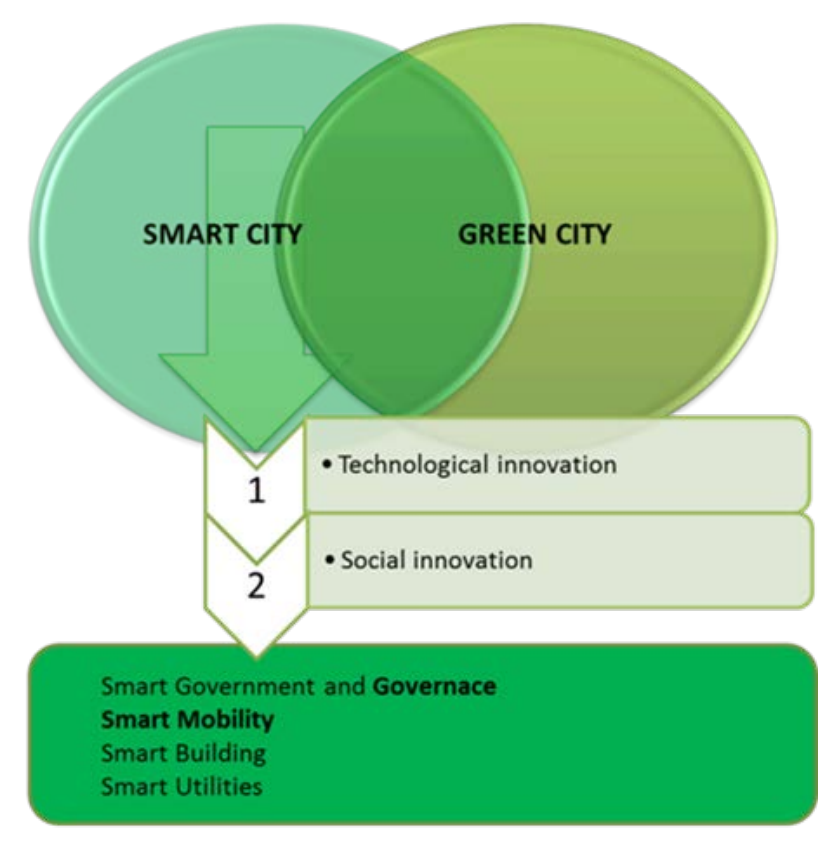

Figure 1: General framework of green smart city approach

Source: own representation

"Smart" and "green" approaches for sustainable mobility in cities would include: modernization of public transport fleets, enhancing the efficiency of the public transport system, the largerscale use of electric cars and bicycles, increasing bike using and sharing, car-sharing and carpooling services, public transport and general traffic monitoring, optimizing parking lots, etc. (Casini, 2017).

Nevertheless, a broader view should be considering the promotion of sustainable and "ecological" transport. Holden (2007) argues that "green" vehicles and infrastructure are not always climate and environmentally friendly, especially if the productions and consumption balance within their life cycle are taken into consideration.

It is highly needed that green and smart dimensions to be integrated into various aspects of city development to co-create the image of the city to outsiders but also residents (Chan \& Marafa, 2017). To be sustainable, the plans and the measures regarding urban transport should be acceptable to the public as they imply changes in travel behaviour (Corpade et al., 2012).

The current paper tries to analyse, from different perspectives how ecological balance and technological innovation are integrated into urban life by using official statistical data, analysing urban mobility strategies, assessing the perception of urban stakeholders and the impact of new approaches on urban image reflected by local newspapers. 
The importance of perceptions and media representations in pushing forward or in being a barrier against promoting change in urban transport has been argued by different scholars. The identification and screening of urban stakeholders and their opinions that play a role in influencing smart cities design were pursued before, but there are some limitations. It is a fact that most of the studies questioning the perception in these fields are extensively focusing on governments, businesses, and research organizations and less on citizens (Marrone \& Hammerle, 2018). Previous research conclusions converge towards the need to discuss not only on technical green and smart but also on a more human perspective that could enhance collaboration and induce acceptability of new solutions (Angelidou, 2015).

Thomas et al. (2016) highlight that a clear definition of smart cities is still missing from everyday vocabulary, while Soma et al. (2018) discuss the role of a better knowledge among a diversity of stakeholders in promoting the transition towards more sustainable urban practices. The massmedia discourse can be a driver that can change public perception and make citizens more aware of the need for promoting smarter and more sustainable cities. In this regard, Monroe (2017) argues that the newspaper's narratives "reveal concerns with not just how people moved through the city, but with the everyday configuration of a rational, modern, biopolitical order" (p. 1). Other approaches can also emerge to a greater extent in the future. For example, Tomaszewska \& Florea (2017) stress social media to be mined to integrate into the decisionmaking process the citizens' perceptions regarding the public transport system. Meanwhile, even if many possible approaches can relate green and smart solution to their social acceptability, the challenges from conceptual, technical, social perspectives, and the importance of general context have to be taken into account.

\section{THE EUROPEAN AND ROMANIAN CONTEXT}

\section{The challenges of building green and smart cities}

Cities in Central and Eastern European countries inherited or acquired numerous problems in different areas such as technical and economic (poor transport infrastructure, a lower degree of innovation, insufficient investments), social (increasing social disparities, a lower urban governance performance) and environmental (congested traffic and air pollution, low and decreasing coverage with green areas, etc.). Sustainable and smart city solutions could tackle some of these problems. However, smart cities solutions are still viewed as a novelty in the countries of the post-communist block (Sikora-Fernandez, 2018). For example, according to a report of the European Smart Cities Organization (ESC, 2020), Romanian cities are still at the beginning of developing and implementing smart solutions. In fact, during the first phase (19992012), only a few cities had initiatives in implementing smart technologies (Hunedoara, lași, Piatra-Neamț, and Sinaia). After 2012, other major cities with a high demographic, cultural, and industrial potential (Bucharest, Cluj-Napoca, Brașov, Timișoara, Craiova, and Sibiu) followed this path in integrating smart solutions (Batagan, 2012). In general, as in this particular cases, smart mobility is one of the main directions of the concept and most often the solutions that are already implemented aim at a more efficient and faster transport, in direct connection with the issues regarding traffic jams, pollution and quality of urban public transport. Most of the projects concern the optimization of the parking lots and payment for parking, traffic monitoring, public transport fleet monitoring, and car charging stations. 
The Romanian cities are worth considering as they epitomize all the above-mentioned difficulties and rank very low at European level when it comes to green and smart development. Most Romanian cities are not meeting the EU requirement of a minimum of $26 \mathrm{~m}^{3}$ of green areas per inhabitant (Ghenai, 2012) and rank very low according to the overall Green City Index, as well as according to indexes reflecting sustainable transport and air quality fields (EIT, 2012; Bănică et al., 2020). Indeed, the shrinkage of green areas (lanoș et al., 2015; Petrișor et al., 2016; Picioruș, 2015) and the increasing urban mobility demand are nowadays two of the greatest challenges that Romanian cities must overcome.

Romanians use less private cars $\left(28 \%\right.$ - the $2^{\text {nd }}$ lowest rate in EU) and are more inclined to use public transport ( $22 \%$ use it at least once a day $-4^{\text {th }}$ highest rate) and to walk ( $81 \%$ walk at least once a day $-7^{\text {th }}$ highest rate) (European Commission, 2012). Nevertheless, these figures-which seem positive-do not come from the existence of healthier and greener cities, but rather from lower motorization rate and lower financial resources that the population can allocate for personal mobility. However, as Romania is passing through a period of robust economic development, the middle class is gaining in size, the motorization rate is rapidly rising and the process of residential urban sprawl is flourishing (lațu et al., 2011). Consequently, one can notice increasing rates of urban mobility that demand sustainable and/or smart solutions. Against this background, a new policy instrument - the sustainable urban mobility plan - has been adopted by Romanian cities following the recommendations of the EU (COM(2009)490; Tomasciuc et al., 2016).

\section{Sustainable urban mobility plans as a main policy instrument}

Urban mobility gained momentum on the EU's policy agenda in the late 2000s, following several decades of a continuous search for best planning solutions. The moment was marked by the adoption of an action plan on urban mobility (COM(2009)490) and by the creation of a new instrument for promoting it in the form of sustainable urban mobility plans (SUMPs). "A Sustainable Urban Mobility Plan is a strategic plan designed to satisfy the mobility needs of people and businesses in cities and their surroundings for a better quality of life. It builds on existing planning practices and takes due consideration of integration, participation, and evaluation principles" (Ruprecht Consult, 2013, p. 8). The following years marked the publication of the first (Ruprecht Consult, 2013) and second (Ruprecht Consult, 2019) SUMP Guideline, to facilitate the dissemination and implementation of the SUMP concept across EU's member states.

European guidelines and national initiatives could be very hard to dissociate from one another. This is true especially in eastern countries, as sometimes the latter arises because of the former. In this regard, tackling increasing urban mobility issues in Romanian cities is a very good example of how European guidelines stimulate national initiatives, which, at their turn, add a personal touch to it. Romania is formally adopting SUMPs to overcome urban mobility problems. However, the results are not always as expected. One may have noticed the slow pace in adopting good governance approaches in the field of urban mobility (Tomașciuc et al., 2015, 2016). Some of the main difficulties are encountered in adopting bottom-up planning approaches and in involving all relevant stakeholders (as highlighted by Tomașciuc et al., 2015), a fact which is supposed to negatively affect the legitimacy of adopted policies (Van Der Linde et al., 2020).

It follows from the above that implementing sustainable urban mobility practices in Romanian cities depends highly not only on the existence of standardized top-down incentives, but also on the proactive engagement of local stakeholders and population. Innovative and coordinated urban planning at all administrative levels is thus essential for achieving sustainability. 
Stakeholders' opinions, public opinion/acceptability, as well as media representations play their part in assuring the successful implementation of sustainable and smart urban transport practices. However, previous research paid little attention to these issues. Against this background, we aim at exploring stakeholders' perception and media coverage of some urban transport issues in Romanian cities. The approach is only explorative as it is not aimed at testing hypothesis, but rather at 1) exploring the opinions of stakeholders concerning the state of urban mobility in Bucharest, lași and Cluj-Napoca, and at 2) identifying the main urban transport issues debated in local newspapers from Iași and Cluj-Napoca.

\section{METHODOLOGY}

The current exploratory approach assesses the transformations occurred in the area of urban mobility from the green and smart cities concepts perspective. It first uses available official statistical databases to highlight the main dynamics in urban transport/mobility. Second, it applies a survey on three categories of stakeholders that could have an influence on urban planning in the selected cities (Bucharest, Cluj-Napoca and lași). Third, the paper briefly analyses the public image of urban transport reflected by local newspapers. Stakeholders' perception and local media reflection of the subject are important, as enhancing smart urban mobility is also a matter of political will, an outcome of the vision/perception from the part of local stakeholders (Axelsson \& Granath, 2018) and a result of local population's participatory attitudes.

\section{Statistical data}

This study makes use of statistical data published by the National Institute of Statistics of Romania. Data are publicly available throughout TEMPO Online database of the institute (INSSE, 2020a, 2020b, 2020c). Table 1 provides an overview of the indicators considered in our analysis to define the actual context and some of the present challenges urban mobility faces in Romania.

Table 1: Transport infrastructure and urban mobility indicators employed in our study

\begin{tabular}{lccccc}
\hline \multirow{2}{*}{ Indicator } & \multirow{2}{*}{ Period } & \multicolumn{3}{c}{ Geographical level } & \multirow{2}{*}{ Reference } \\
\cline { 3 - 4 } & & National & County & Local & \\
$\begin{array}{l}\text { Passengers transported with } \\
\text { local public transport by mode }\end{array}$ & $1990-2019$ & $\mathrm{Y}$ & $\mathrm{Y}$ & $\mathrm{N}$ & $\begin{array}{c}\text { INSSE } \\
(2020 \mathrm{a})\end{array}$ \\
$\begin{array}{l}\text { Town street length } \\
\begin{array}{l}\text { Length of modernized town } \\
\text { streets }\end{array}\end{array}$ & $1990-2018$ & $\mathrm{~N}$ & $\mathrm{~N}$ & $\mathrm{Y}$ & $\begin{array}{l}\text { INSSE } \\
(2020 \mathrm{~b})\end{array}$ \\
\hline
\end{tabular}

${ }^{1} \mathrm{Y}=$ data available at the specified geographical level, $\mathrm{N}=$ data not available at the specified geographical level 


\section{Exploring perceptions of academics, local administration and transport experts}

The perception of local stakeholders was evaluated using a qualitative method that is largely used, i.e. questionnaire survey (Ilovan \& Doroftei, 2017). The survey was applied online and took into consideration nine big Romanian cities, but most of the results refer to three important cities in Romania: Bucharest, Cluj-Napoca and lași. Therefore, the present analysis will concentrate on these three cities. Most of the answers came from the academic environment, i.e. teaching staff and researchers that activate in domains that imply human mobility and transport.

A total of 140 questionnaires were validated, more than a half being from academics, while local administration and transport experts account for $38 \%$ of the respondents (Figure 2 ).

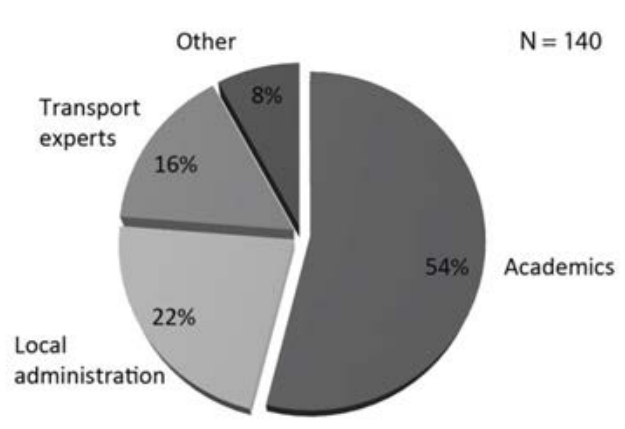

(a)

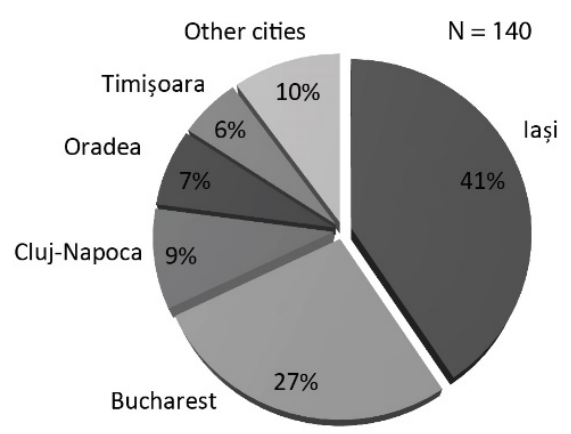

(b)

Figure 2: The structure of the sample used for the survey by: (a) Field of work; (b) city Source: own representation

The geographic distribution of the answers is not very well balanced as most of the answers came from the cities of lași and Bucharest. Answers from Western geographic regions of Romania came from three different cities: Cluj, Oradea and Timișoara (22\% of the total).

Most of the respondents have a good experience of working in their fields that are related, more or less, to transport systems (Figure 3). A number of 100 answers came from stakeholders that have more than 10 years' experience in their fields. Thus, most of the opinions came from respondents that are supposed to have a good knowledge on urban mobility issues related to their cities and, at the same time, that are better positioned to evaluate current/recent trends in the field.

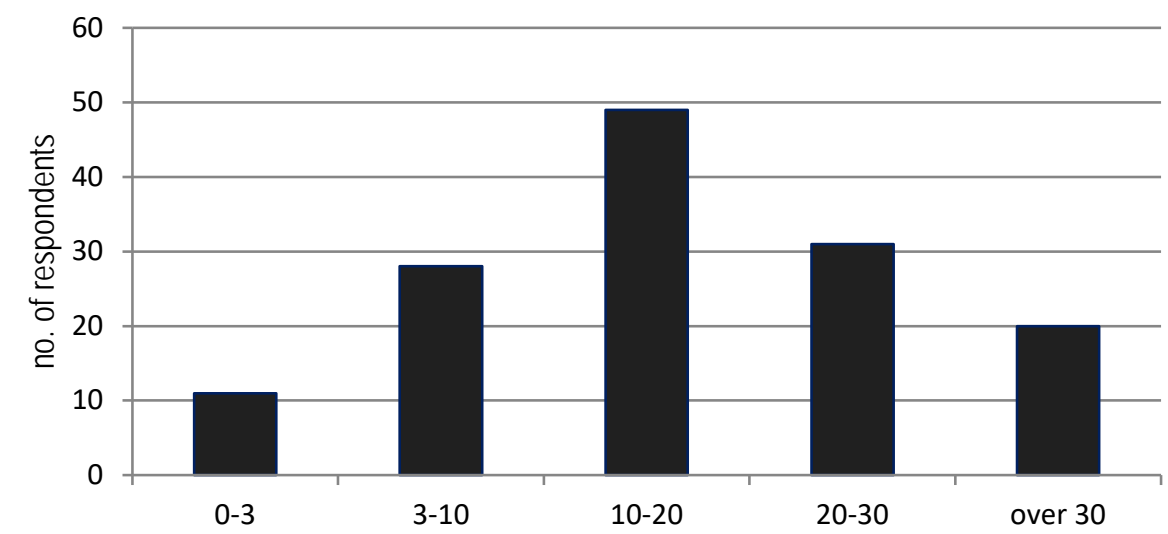

Figure 3: The structure of the sample used for the survey by years of experience in work Source: own representation 


\section{The reflection of urban transport issues in local newspapers}

Finally, our methodological approach completed the multi-faceted exploration of how green and smart mobility are represented in public by an overall scan of the local press. We only took a comparison between lași and Cluj-Napoca to acknowledge if there were patterns in associating urban transport to an ecologic or technology-oriented perspective.

Aspects related to urban transport image in Cluj-Napoca and lași were also explored by employing content cloud analysis of local newspapers. Content cloud, also called 'word cloud' or 'tag cloud', is an exploratory qualitative data analysis (Cidell, 2010), aimed at summarizing the content of documents by computing word frequencies and representing them visually. When combined with geographical location, "content clouds provide a powerful way to summarise and compare information from different places on a single issue" (Cidell, 2010). The last five years witnessed plenty of studies that employ content cloud analysis. As a matter of fact, this technique has been recently employed in geographical studies to inquire, inter alia, issues related to identities of cities as reflected in news articles (Oliveira Capela \& RamirezMarquez, 2019), sense of place dynamics reflected in daily newspapers (Buchanan, 2009) and local environment perception reflected in crowdsourced photo geodata (Dunkel, 2015).

The objective was to highlight the main 100/50 keywords employed in articles dealing with issues of urban transport. A number of 74 local newspaper articles were selected for the analysis (37 for each of the two cities). One well-known and representative local newspaper was selected for each of the two cities: "Ziarul de lași" and "Monitorul de Cluj". The selection of the 74 articles was conducted following two criteria: the article was published in the online version of the newspaper during 2010-2020, being one of the first 37 articles in Google search engine. The online search was conducted similarly for the two newspapers and it was based on searching for articles related to the word "transport".

\section{RESULTS AND DISCUSSION}

\section{Outcomes of policies implemented during the last 15 years}

Like most of the eastern European cities, Romanian cities have a strong legacy of public transport (ECORYS, 2006). However, between the fall of the communist regime and the accession into the European Union, one can hardly speak about urban planning strategies at the local level. Thus, in the first phase, we analysed statistical data on urban transport infrastructure and mobility over the last 15 years to identify the main outcomes of actions implemented during this period.

As a general trend, one can notice that fossil fuel transport was given priority during the last decades. Busses and minibuses were preferred, while the infrastructure for electric transport modes (trams, trolleybuses, metro, electric buses) was given less attention, although the highest increase in total number of passengers was registered by metro transport (Figure 4). This came with the price of decreasing quality of transport services and lower number of passengers, most notably in the case of the number of passengers transported by trams and trolleybuses. The only underground network is currently under operation in Bucharest. The number of passengers dropped sharply during the 1990s, but then underwent a revival during the first part of the 2000s. Further extensions of the Bucharest Metro system are under construction, while the Municipality of Cluj-Napoca is taking into consideration the possibility of building its first underground Metro line (Metro Report International, 2020). Meanwhile, the transition of the buses fleet from fossil fuels towards more environmentally friendly technologies is taken into 
account as investments in electric buses are being made by local authorities in lași, Cluj-Napoca and Bucharest (among other cities) (VEGACOMP, 2020).

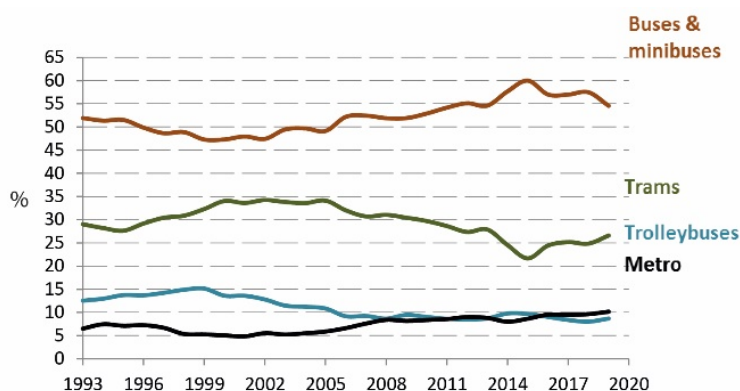

(a)

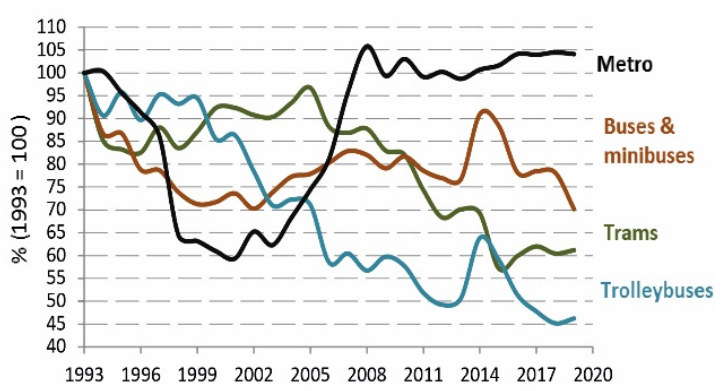

(b)

Figure 4: (a) Evolution of modal split of urban public transport in Romania (own elaboration, according to data from INSSE, 2020a); (b) Evolution of the number of passengers transported with local public transport (own elaboration, according to data from INSSE, 2020a)

Local administrations implemented numerous projects since Romania joined the EU. In fact, during the last 13 years, the largest Romanian cities underwent advanced more in implementing European policies, which resulted in important investments in urban mobility projects. Yet, these investments focused more on building critical transport infrastructure than on developing smart transport networks and services. This should not be surprising as in most cases critical infrastructure was missing, as suggested in Table 2. Moreover, the intensification of urban sprawl added pressure on local authorities for building new roads serving new residential areas.

Table 2: Percentage of modernised* roads within each city

\begin{tabular}{llllll}
\hline \multicolumn{1}{c}{ City } & $\mathbf{1 9 9 0}$ & $\mathbf{2 0 0 0}$ & $\mathbf{2 0 0 7}$ & $\mathbf{2 0 1 3}$ & $\mathbf{2 0 1 8}$ \\
\hline Bucharest & 44.76 & 46.02 & 52.44 & 73.56 & 73.96 \\
Cluj-Napoca & 51.17 & 47.37 & 79.69 & 94.79 & 95.78 \\
Iași & 66.60 & 68.13 & 69.32 & 71.88 & 73.14 \\
\hline
\end{tabular}

*Modernised town streets $(\mathrm{km})=$ streets with shaped-stone, asphalt, or concrete covering. The parts paved with shaped stone include coverings of cubic, parallelepiped stone or stone of other regular shapes (according to data from INSSE, 2020b, 2020c)

In the early 1990s, Cluj-Napoca had only half (51\%) of the road network covered with shapedstone, asphalt or concrete, while lași (67\%) and Bucharest (45\%) were also suffering from lack of a fully modern network of transport infrastructure. However, starting with early 2000s, ClujNapoca underwent an accelerated process of urban development, including a modernisation process of the transport network. In 2018, almost the entire length of the road network has been modernised (95.78\%), while lași is now lagging behind (with only 73.14\%).

Investments in transport infrastructures were not part of any integrated local transport strategy during 2007-2013 financial period, as it is the case starting with the new financial period. In the new financial framework (2014-2020), the main instrument used to promote a coherent and sustainable development of cities is the SUMP. However, their adoption during the last six years encountered numerous obstacles, of which the lack of tradition in good governance approaches stands apart. 


\section{Scholars', local administration's and transport experts' opinions on urban mobility issues}

The three cities of Romania that were chosen as case studies are evolving at different paces, with Cluj-Napoca taking the lead in sustainable urban mobility. According to questionnaires, the main stakeholders's perception supports this statement. Cluj-Napoca is a leading city for all the indicators we took into consideration (Figures 5 and 6). Bucharest and lași are lagging far behind, without a clear distinction between their perceived performances: Iași has a better perceived public transport and a better perceived intelligent signalling, while Bucharest is viewed as assuring a higher quality of transport infrastructure in the central area, a higher degree of interconnectivity and better performance in terms of exclusive lanes for public transport (compared to lași).

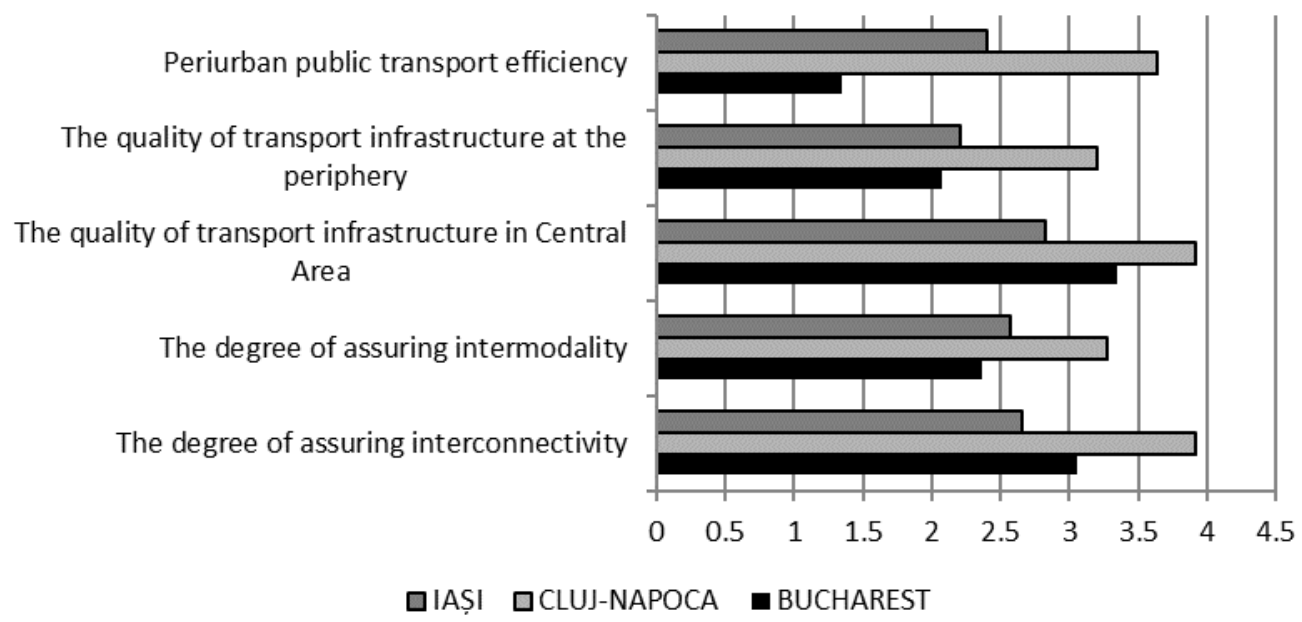

Figure 5: The average scores for different topics of urban transport in the analysed cities

The adoption of different solutions for increasing the efficiency of urban transport from both technological and ecological points of view is also differently perceived among the three cities. Cluj-Napoca is once again performing far better than lași and the capital city. Bikes rental, the tracking of public transport with GPS, real-time schedules and exclusive lanes for public transport are measures that had the highest rate of success in implementing. By contrast, in lași, only intelligent signalling and traffic lights and bicycle infrastructure were introduced to a certain degree, while Bucharest is perceived to lag in the implementation process.

Exclusive lanes for public transport

Schedules displayed in real-time transport stations

The endowment of transport means with GPS

Bike rental places

Bike lanes

Electric buses or minibuses Intelligent signaling / Traffic lights

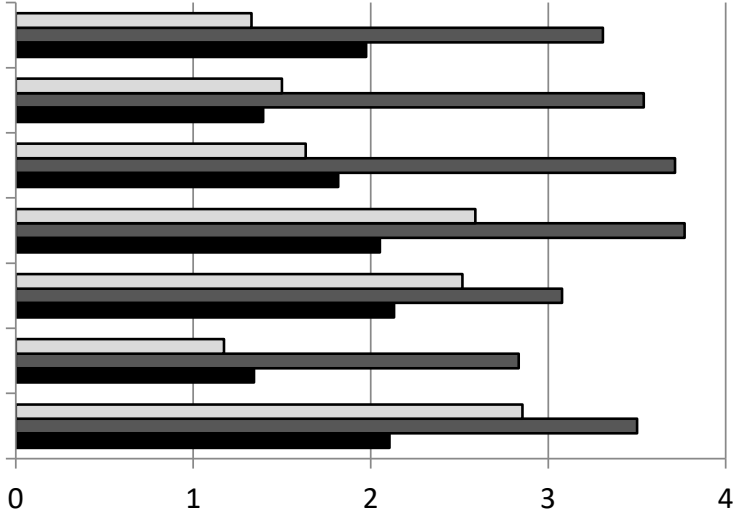

口IAȘI $\square$ CLUJ-NAPOCA B BUCHAREST

Figure 6: The degree of implementing certain innovations in public transport in three important Romanian cities - average scores $(0=$ not implemented, $5=$ fully implemented $)$ 
Although the general perception is that traffic has a significant negative impact on air quality and life quality in the city (Figure 8 ), a very high percentage (40\%) of respondents would prefer good accessibility by car over life quality (Figure 7a). At the same time, 37\% of the total number of respondents acknowledges that they know about the existence of at least one impact assessment of traffic air pollution on health (Figure $7 \mathrm{~b}$ ).

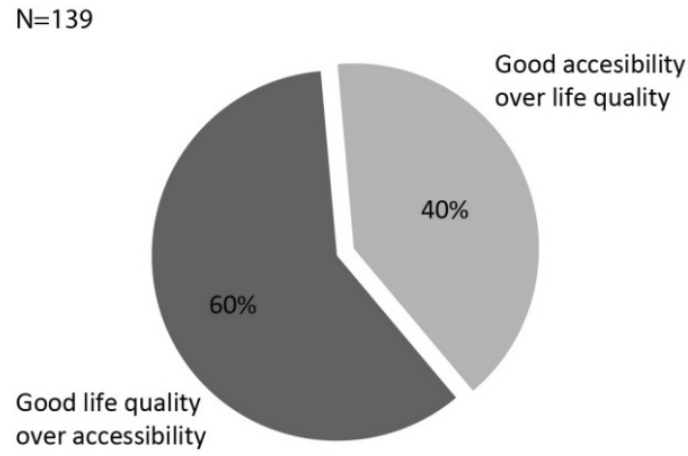

(a)

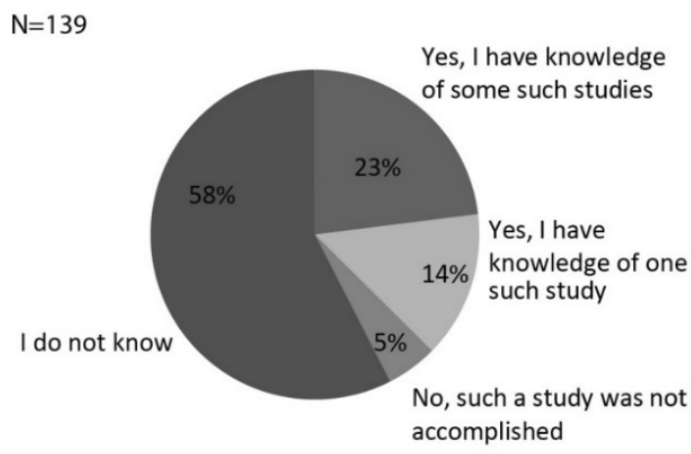

(b)

Figure 7: (a) Prioritizing between accessibility by car and life quality in the urban environment; (b) Knowledge about the existence of impact assessments of traffic air pollution health effects

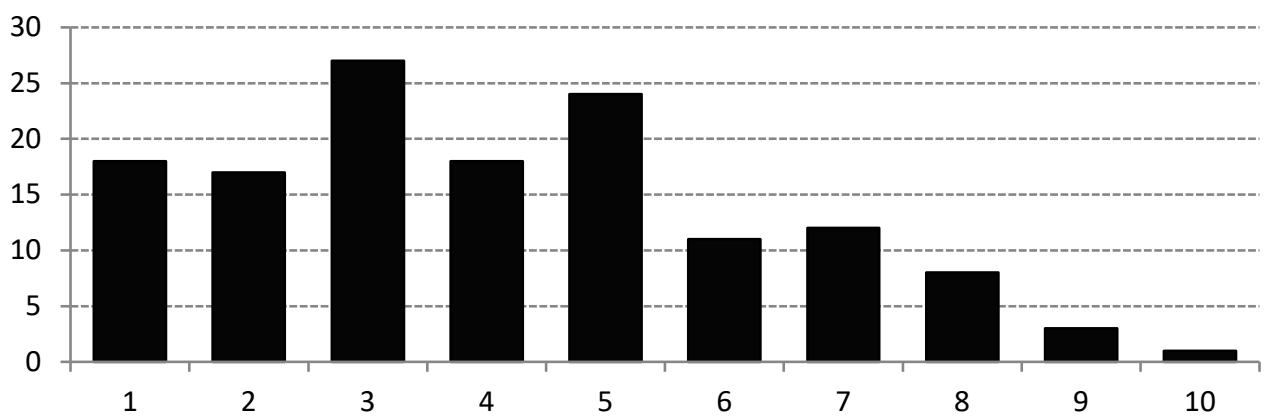

Figure 8: The perception of traffic contribution to air pollution in cities (scores 1-10) (1- major negative impact, 10 - no negative impact)

Indeed, Figure 8 shows an overwhelming contribution of local authorities and transport experts in the decision-making process. By comparing this fact against the conceptual background defined by Ruprecht Consult $(2013,2019)$, we can conclude that the actual decision-making process resonates more with the traditional planning of urban mobility than to the sustainable planning of it. 


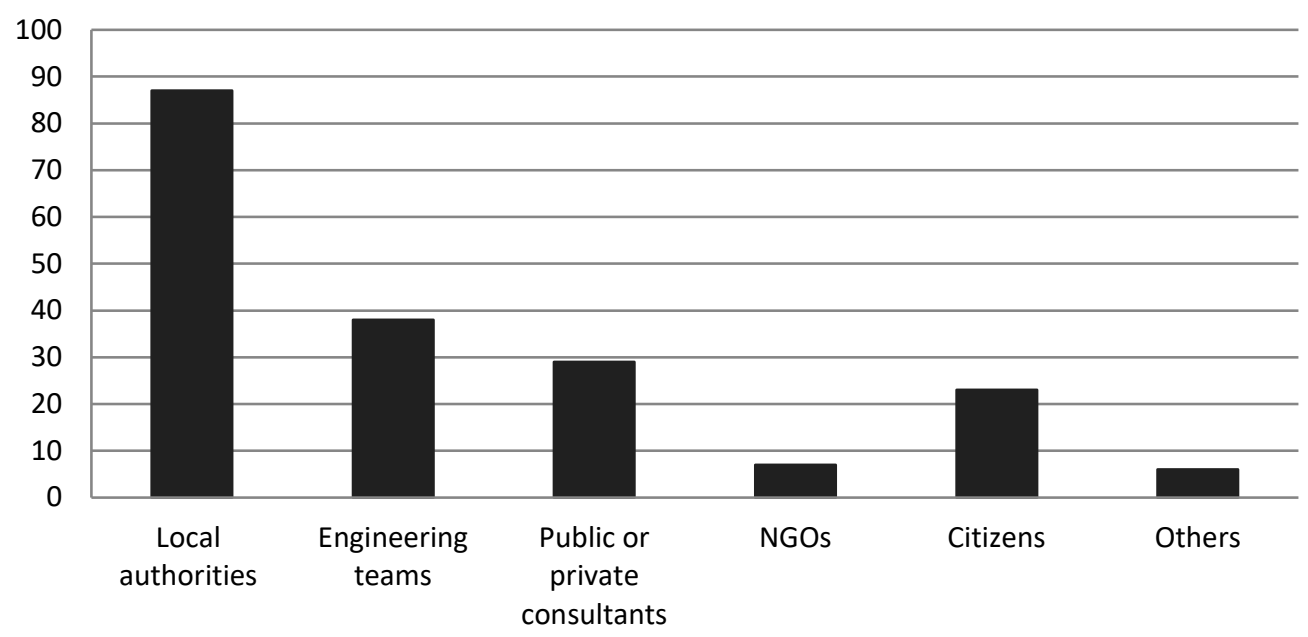

Figure 9: The contribution on planning the actual transport system (Sum of scores, that were expressed in the questionnaire on a 1 to 5 scale)

Furthermore, the high influence of local authorities and engineering teams (Figure 9) suggests a rather top-down approach, whereas a bottom-up one would be more desirable. Some recent studies even describe the SUMP effort in Romania as being a "catching up" process, arguing that "because of the lack of general education on the mobility issue of the population, businesses, technicians and the political class, this catching up appears as an imported concept, not a homegrown need and phenomenon, and it occurs with little coherence or coordination" (May et al., 2017, p. 9).

\section{The reflection of urban transport issues in local newspapers}

Content cloud generation allows us to depict the representative keywords related to urban transport in each main local newspaper from lași and Cluj-Napoca. Keywords and concepts employed in various discourses are important in building urban identity. As Oliveira Capela and Ramirez-Marquez (2019, p. 74) stated: "an important aspect of how cities develop their identities is based on the exchange of information through a variety of sources. Individuals hold opinions and knowledge of a place by watching movies, meeting residents or tourists, watching the news, reading newspapers, magazines, and blogs". Furthermore, "local community information is critical to maintaining civic engagement and participation" (Han et al., 2014, p. 1).

Results show that, in both cases, the main keywords employed reflect issues related to public transport ("public", "line", "user", "person", "passenger", "free") (Figure 10). This could be interpreted in the light of the relative importance of public transport in Romanian post-socialist cities, that still rely a great deal on public transport compared to western ones. However, it can also be interpreted as a bias coming from the chosen keyword ("transport"), which might have led to the exclusion of articles strictly dealing with road traffic and pedestrian mobility (i.e. articles that might not employ the word "transport").

A closer analysis of the top 50 keywords (Figure 11) employed in the case of the two cities shows the same similarity related to the importance of public transport. However, there are two notable differences. 

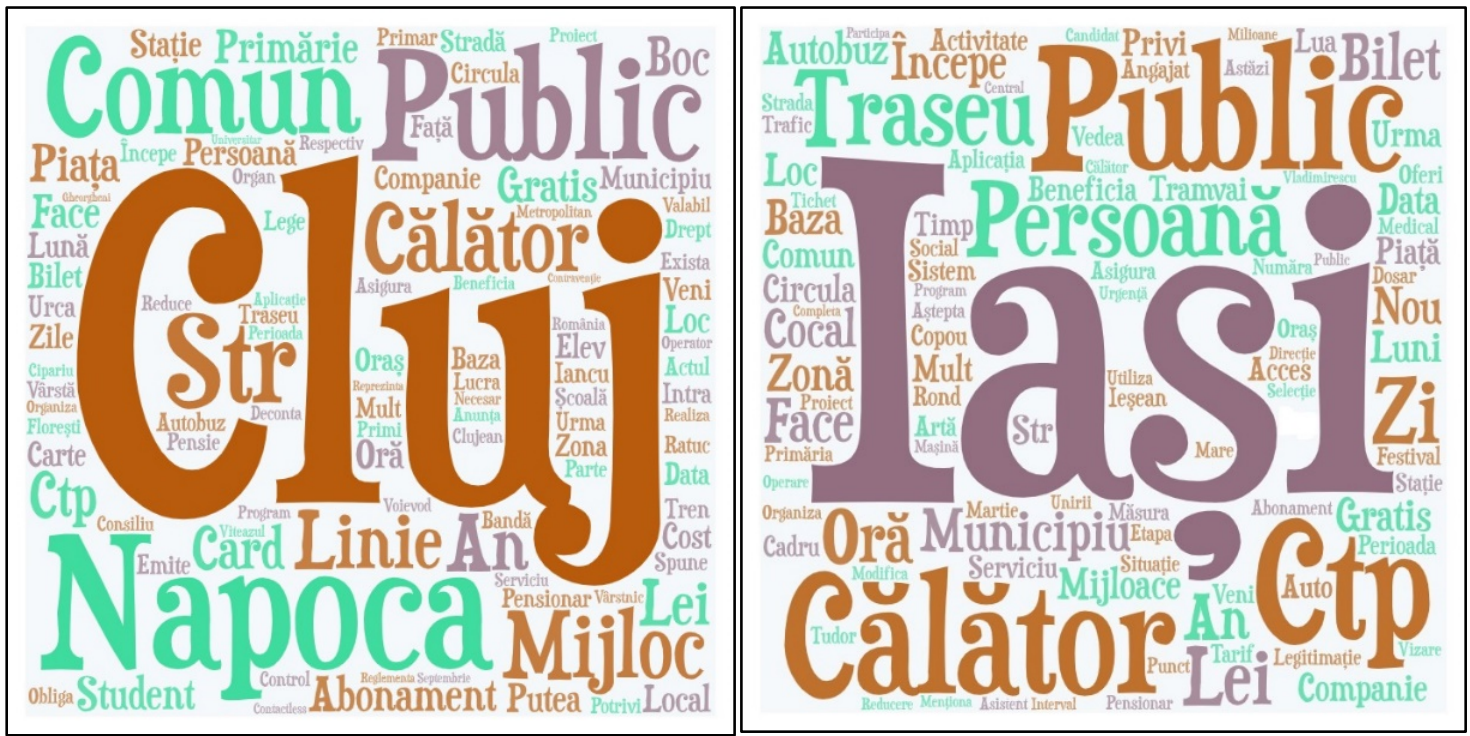

Figure 10: Most frequent 100 words in the case of Cluj-Napoca and Iași respectively

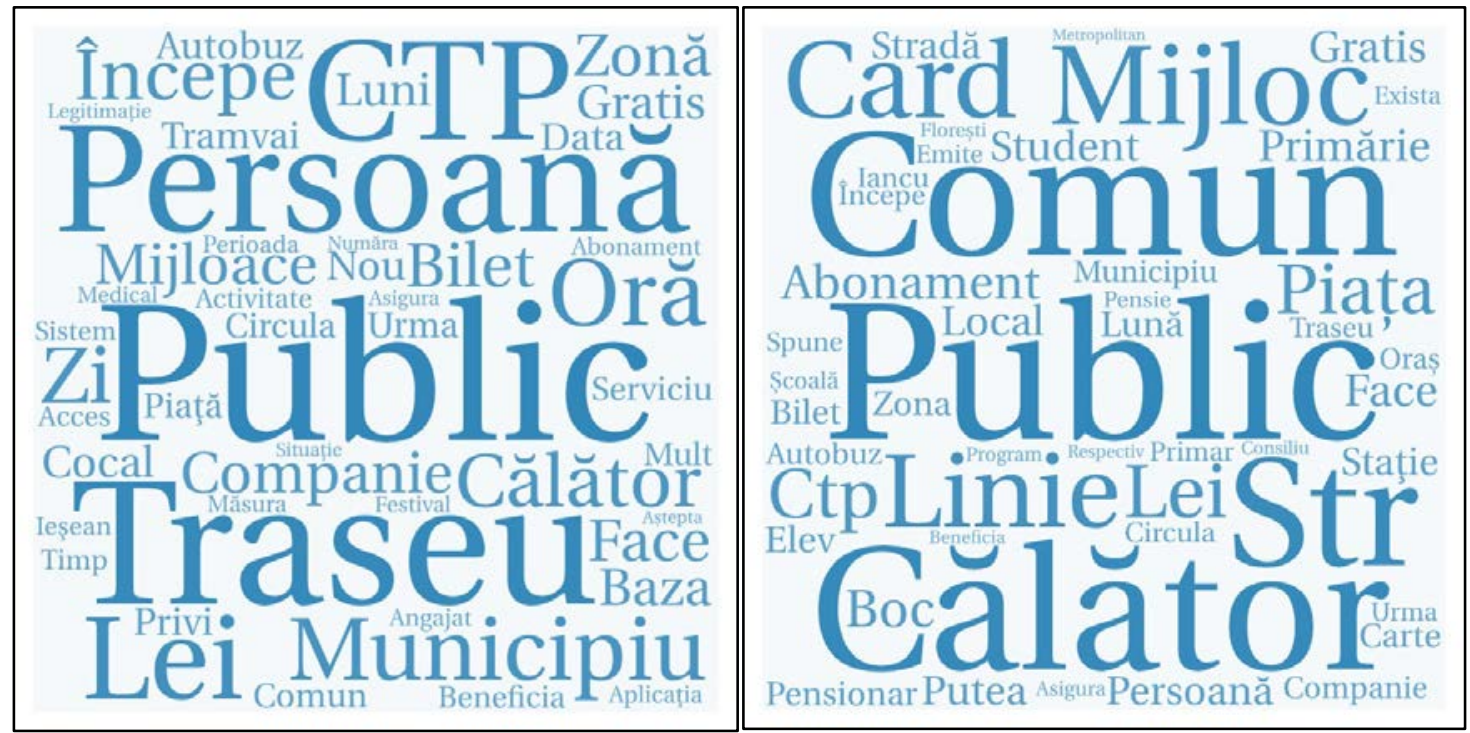

Figure 11: Most frequent 50 words in the case of Cluj-Napoca and Iași respectively

The articles from "Monitorul de Cluj" do employ words related to the metropolitan area of ClujNapoca ("metropolitan" and "Florești"), while such words are absent in the case of Iași. This pinpoints to the fact that the local media of Cluj-Napoca might identify their city as being metropolitan to a higher degree compared to the newspapers of lași. Another interesting fact is revealed by two words reflecting issues of modernization of public transport services: "card" and "pass" ("abonament") are among the top ten keywords employed in the case of ClujNapoca, while in the case of Iași, "card" is absent and "pass" in less frequent (the $36^{\text {th }}$ rank). However, in the case of lași, we found the word "application", although it is not very frequent (the $28^{\text {th }}$ rank). Such issues are hard to be related to urban identity; however, they show a greater propensity from Cluj-Napoca Municipality to take practical steps towards promoting smart and sustainable solutions, a fact which is in line with the results from our questionnaire. 


\section{CONCLUSIONS}

This study has explored the stakeholders' perceptions and the local newspapers coverage of some aspects related to smart and sustainable urban mobility in three major Romanian cities (Bucharest, Cluj-Napoca and lași). Results reported in the current paper are preliminary. However, they pinpoint some interesting facts that could be the start for more in-depth studies.

Stakeholders' perceptions lead us towards the following conclusions:

First, there is an overwhelming influence of local authorities and transport engineers in the decision-making process, a fact that is contrary to sustainable and good governance practices. The decisive role in urban management is thus taken by these two stakeholder categories, while other professionals are hardly integrated into the decision process. Therefore, a significant part of stakeholders questioned complain of being ignored (or not informed) during the planning processes and decision making. However, all categories of stakeholders' state that they are willing to contribute to promoting environmentally friendly transport.

Second, stakeholders' perceptions suggest that in all three cities, some "traditional" problems of urban mobility such as those related to urban air pollution are still perceived to be major (a fact which is in line with official statistical data concerning air quality in urban areas). This could be interpreted as a consequence of the fact that none of the three studied cities succeeded in limiting the impact of high use of individual passenger cars.

The second section of the exploratory analysis - the content analysis of local newspapers coverage of transport issues - pinpoints the high importance of public transport in Romanian post-socialist cities for the general public, but also a rather incipient emergence of green and smart practices. The latter information is also confirmed by the stakeholders' perceptions, who suggested that the implementation of smart green mobility in Romania is at an early phase in both simple measures and complex IT-related equipment installation.

Finally, according to stakeholders' perceptions and local newspapers coverage of urban transport issues, the inquired cities envisage different stages in planning and implementing sustainable transport solutions. Overall, in the last 10 years, Cluj-Napoca showed clearer signs of sustainable modernization and proved to be more open to smart and green solutions, while in lași and Bucharest these processes also occurred, although at slower paces.

\section{REFERENCES}

AHVENNIEMI, H., HUOVILA, A., PINTO-SEPPÄ, I., \& AIRAKSINEN, M. (2017). What Are the Differences between Sustainable and Smart Cities? Cities, 60, 234-245. https://doi.org/10.1016/j.cities.2016.09.009

ALBINO, V., BERARDI, U., \& DANGELICO, R. (2015). Smart Cities: Definitions, Dimensions, Performance, and Initiatives. Journal of Urban Technology, 22(1), 3-21. http://dx.doi.org/10.1080/10630732.2014.942092

ANGELIDOU, M. (2014). Smart City Policies: A Spatial Approach. Cities, 41, S3-S11.

ANGELIDOU, M. (2015). Smart Cities: A Conjuncture of Four Forces. Cities, 47, 95-106.

AXELSSON, K. \& GRANATH, M. (2018). Stakeholders' Stake and Relation to Smartness in Smart City Development: Insights from a Swedish City Planning Project. Government Information Quarterly, 35(4), 693-702. https://doi.org/10.1016/j.giq.2018.09.001.

BĂNICĂ, A., ISTRATE, M., \& MUNTELE, I. (2020). Towards Green Resilient Cities in Eastern European Union Countries. Journal of Urban and Regional Analysis, 12(1), 53-72. https://doi.org/10.37043/JURA.2020.12.1.4 
BATAGAN, L. (2012). The Use of Intelligent Solutions in Romanian Cities. Informatica Economica, 16, 4, 37.

BRIA, F. (2012). New Governance Models towards an Open Internet Ecosystem for Smart Connected European Cities and Regions. Open Innovation (pp. 62-71). Directorate-General for the Information Society and Media, European Commission. Retrieved April 10 2020, from https://ec.europa.eu/digital-singlemarket/en/news/open-innovation-2012

BUCHANAN, C. (2009). Sense of Place in the Daily Newspaper. Aether: The Journal of Media Geography, 4, 62-84.

CARMONA, M., TIESDELL, S., HEATH, T., \& OC, T. (2010). Public Places Urban Spaces. The Dimensions of Urban Design. London and New York: Routledge.

CASINI, M. (2017). Green Technology for Smart Cities. IOP Conference Series: Earth and Environmental Science, 83, 12014.

CHAN, C.-S. \& MARAFA, L.M. (2017). How a Green City Brand Determines the Willingness to Stay in a City: The Case of Hong Kong. Journal of Travel \& Tourism Marketing, 34(6), 719-731. https://doi.org/10.1080/10548408.2016.1236768

CHAPMAN, L. (2007). Transport and Climate Change: A Review. Journal of Transport Geography, 15(5), 354-367.

CIDELL, J. (2010). Content Clouds as Exploratory Qualitative Data Analysis. Area, 42(4), 514-523.

COLDING, J. \& BARTHEL, S. (2017). An Urban Ecology Critique on the "Smart City" Model. Journal of Cleaner Production, 164, 95-101. https://doi.org/10.10-16/j.jclepro.2017.06.191

COM(2009)490 final. Action Plan on Urban Mobility. Communication from the Commission to the European Parliament, the Council, the European Economic and Social Committee and the Committee of the Regions.

CORPADE, A.-M., CORPADE, C., \& IONESCU, C.-T. (2012). Challenges for Sustainable Mobility in Cluj-Napoca Metropolitan Area, Romania. Journal of Settlements and Spatial Planning, 3(2), 181-186.

DE JONG, M., JOSS, S., SCHRAVEN, D., ZHAN, C., \& WEIJNEN, M. (2015). Sustainable-Smart-Resilient-Low CarbonEco-Knowledge Cities; Making Sense of a Multitude of Concepts Promoting Sustainable Urbanization. The Journal of Cleaner Production, 109, 25-38.

DUNKEL, A. (2015). Visualizing the Perceived Environment Using Crowdsourced Photo Geodata. Landscape and Urban Planning, 142, 173-186.

ECONOMIST INTELLIGENCE UNIT (EIT) (2012). European Green City Index: Assessing the Environmental Performance of 30 Major European Cities. Retrieved April 10 2020, from http://www.siemens.com/entry/cc/de/greencityindex.htm

ECORYS (2006). Study on Strategic Evaluation on Transport Investment Priorities under Structural and Cohesion Funds for the Programming Period 2007-2013, No 2005.CE.16.0.AT.014, ECORYS Nederland BV, Rotterdam, November 2006. Retrieved April 18 2020, from link: https://trimis.ec.europa.eu/project/study-strategicevaluation-transport-investment-priorities-under-structural-and-cohesion

EUROPEAN COMISSION (EC) (2019). Mission Letter. Commission of Transport, 1 December 2019. Retrieved April 18 2020, from https://ec.europa.eu/commission/sites/beta-political/files/president-elect_von_der_leyens_mis sion_letter_to_adina_valean_1.pdf

EUROPEAN COMMISSION (EC) (2012). Communication from the Commission. Smart Cities and Communities-European Innovation Partnership. Brussels. Retrieved April 18 2020, from http://ec.europa.eu/energy/technology/initiatives/doc/2012_4701_smart_cities_en.pdf

EUROPEAN SMART CITIES (ESC) 2012. Centre of Regional Science Vienna University of Technology. Retrieved March 18 2020, from http://www.smart-cities.eu/model.html

EUROPEAN SMART CITIES. CENTRE OF REGIONAL SCIENCE VIENNA UNIVERSITY OF TECHNOLOGY (2012). The Smart City Model. Retrieved April 10 2020, from http://www.smart-cities.eu/model.html

GHENAI, C. (ed.) (2012). Sustainable Development-Energy, Engineering and Technologies-Manufacturing and Environment. InTech. https://doi.org/10.5772/1404

HAN, K., SHIH, P.C., \& CARROLL, J.M. (2014). Local News Chatter: Augmenting Community News by Aggregating Hyperlocal Microblog Content in a Tag Cloud. International Journal of Human-Computer Interaction, 30(12), 1003-1014.

HIREMATH, R.B., BALACHANDRA, P., KUMAR, B., BANSODE, S.S., \& MURALI, J. (2013). Indicatorbased Urban Sustainability - A Review. Energy for Sustainable Development, 17, 555-563. http://dx.doi.org/10.1016/j.esd.2013.08.004. 
HOLDEN, E. (2007). Achieving Sustainable Mobility. Everyday and Leisure-Time Travel in the EU. Aldershot: Ashgate.

IANOŞ, I., SîRODOEV, I., PASCARIU, G., \& HENEBRY, G. (2015). Divergent Patterns of Built-up Urban Space Growth Following Post-socialist Changes. Urban Studies, 53(15), 3172-3188. https://doi.org/10.1177/0042098015608568

IAȚU, C., MUNTEANU, A., BOGHINCIUC, M., CERNESCU, R., \& IBĂNESCU, B. (2011). The Effects of Transportation System on the Urban Sprawl Process for the City of Iași, Romania. Urban Transport XVII: Urban Transport and the Environment in the 21st Century, 116, 291-302.

ILOVAN, O.-R. \& DOROFTEI, I. (eds.) (2017). Qualitative Research in Regional Geography. A Methodological Approach. Cluj-Napoca: Presa Universitară Clujeană.

INSSE (2020a). Table GOS114B - Number of Passengers Transported with Local Public Transport by Macroregions, Development Regions and Counties. Retrieved May 10 2020, from http://statistici.insse.ro:8077/tempoonline/\#/pages/tables/insse-table

INSSE (2020b). Tabel GOS104A - Town Street Length by Counties and Localities. Retrieved May 10 2020, from http://statistici.insse.ro:8077/tempo-online/\#/pages/tables/insse-table

INSSE (2020c). Table GOS105A - Length of Modernized Town Streets by Counties and Localities. Retrieved May 10 2020, from http://statistici.insse.ro:8077/tempo-online/\#/pages/tables/insse-table

KOURTIT, K. \& NIJKAMP, P. (2012). Smart Cities in the Innovation Age. Innovation: The European Journal of Social Science Research, 25(2), 93-95.

LAZAROIU, G. C. \& ROSCIA, M. (2012). Definition Methodology for the Smart Cities Model. Energy, 47(1), 326-332.

MARRONE, M. \& HAMMERLE, M. (2018). Smart Cities: A Review and Analysis of Stakeholders' Literature. Business \& Information Systems Engineering, 60(3), 197-213. https://doi.org/10.1007/s12599-018-0535-3.

MARSAL-LLACUNA, M.-L., COLOMER-LLINÀS, J., \& MELÉNDEZ-FRIGOLA, J. (2015). Lessons in Urban Monitoring Taken from Sustainable and Liveable Cities to Better Address the Smart Cities Initiative. Technological Forecasting and Social Change, 90(B), 611-622. http://dx.doi.org/10.1016/j.techfore.2014.01.012

MAY, A., BOEHLER-BAEDEKER, S., DELGADO, L., DURLIN, T., ENACHE, M., \& VAN DER PAS, J.-W. (2017). Appropriate National Policy Frameworks for Sustainable Urban Mobility Plans. European Transport Research Review, 9(1), 7. https://doi.org/10.1007/s12544-017-0224-1

METRO REPORT INTERNATIONAL (2020). Cluj-Napoca Studies Metro Options. Retrieved March 18 2020, from https://www.railwaygazette.com/projects-and-planning/cluj-napoca-studies-metro-options/56385.article

MONROE, K.V. (2017). Circulation, Modernity, and Urban Space in 1960s Beirut. History and Anthropology, 28(2), 188-210.

NÆSS, P. \& VOGEL, N. (2012). Sustainable Urban Development and the Multi-Level Transition Perspective. Environmental Innovation and Societal Transitions, 4, 36-50. https://doi.org/10.1016/j.eist.2012.07.001

OLIVEIRA CAPELA, F. DE \& RAMIREZ-MARQUEZ, J.E. (2019). Detecting Urban Identity Perception via Newspaper Topic Modelling. Cities, 93, 72-83.

PENTIKOUSIS, K., DONGMING, Z., \& WANG, H. (2011). Network Infrastructure at the Crossroads the Emergence of Smart Cities. $15^{\text {th }}$ International Conference on Intelligence in Next Generation Networks, 109-114. https://doi.org/10.1109/ICIN.2011.6081056

PETRIŞOR, A.I., ANDRONACHE, I.C., PETRIŞOR, L.E., CIOBOTARU, A.M., \& PEPTENATU, D. (2016). Assessing the Fragmentation of the Green Infrastructure in Romanian Cities Using Fractal Models and Numerical Taxonomy. Procedia Environmental Sciences 2016, 32, 110-123. https://doi.org/10.1016/j.proenv.2016.03.016

PICIORUȘ, M.D (2015). Coridoare verzi: pentru reziliență urbană și durabilitate în Zona Metropolitană lași [Green Corridors: For Urban Resilience and Sustainability in laşi Metropolitan Area]. In Bănică, A. \& Muntele, I. (eds.), Reziliență și teritoriu. Operaționalizare conceptuală și perspective metodologice [Resilience and Territory. Conceptual Operationalization and Methodological Perspectives] (pp. 215-233). Iași: Editura Terra Nostra.

ROCHE, S., NABIAN, N., KLOECKL, K., \& RATTI, C. (2012). Are 'Smart Cities' Smart Enough? Global Geospatial Conference Spatially Enabling Government, Industry and Citizens, 14-17 May 2012, Québec City, Canada. Retrieved April 10 2020, from http://www.gsdi.org/gsdiconf/gsdi13/papers/182.pdf 
RUPRECHT CONSULT (2013). Guidelines. Developing and Implementing a Sustainable Urban Mobility Plan. Brussels: European Commission: Directorate-General for Mobility and Transport. Retrieved March 18 2020, from https://www.eltis.org/sites/default/files/guidelines-developing-and-implementing-a-sump_final_web_jan2014b.pdf

RUPRECHT CONSULT (2019). Guidelines for Developing and Implementing a Sustainable Urban Mobility Plan. Second Edition. Brussels: European Commission: Directorate-General for Mobility and Transport. Retrieved March 18 2020, from https://www.eltis.org/sites/default/files/sump-guidelines-2019_mediumres.pdf

SASSEN, S. (2011). Talking Back to Your Intelligent City. McKinsey Publishing. Retrieved March 11 2020, from <http://whatmatters.mckinseydigital.com/cities/talking-back-to-your-intelligent-city>

SIKORA-FERNANDEZ, D. (2018). Smarter Cities in Post-socialist Country: Example of Poland. Cities, 78, 52-59.

SOMA, K., DIJKSHOORN-DEKKER, M.W.C., \& POLMAN, N.B.P. (2018). Stakeholder Contributions through Transitions towards Urban Sustainability. Sustainable Cities and Society, 37, 438-450. https://doi.org/10.1016/j.scs.2017.10.003

SULTANA, S., SALON, D., \& KUBY, M. (2019). Transportation Sustainability in the Urban Context: A Comprehensive Review. Urban Geography, 40(3), 279-308.

THOMAS, V., WANG, D., MULLAGH, L., \& DUNN, N. (2016). Where's Wally? In Search of Citizen Perspectives on the Smart City. Sustainability, 8:207.

TOMASCIUC, A.-I., EVA, M., \& IAȚU, C. (2015). Mechanisms of Territorial Governance in Post-Socialist Periruban Areas from the Perspective of Local Public Authorities. A Case Study on Localities from the Proximity of Suceava City (Romania). Lucrările Seminarului Geografic "Dimitrie Cantemir", 39, 73-86.

TOMASCIUC, A.-I., EVA, M., HAPCIUC, O., \& IAȚU, C. (2016). Spatial Accessibility and Public Transport Issues in PostSocialist Metropolitan Areas: A Case Study of Suceava (Romania). $16^{\text {th }}$ International Multidisciplinary Scientific GeoConference SGEM 2016, SGEM2016 Conference Proceedings, June 28 - July 6, 2016, 2(3), 431-438.

TOMASZEWSKA, E.J. \& FLOREA, A. (2018). Urban Smart mobility in the Scientific Literature-Bibliometric Analysis. Engineering Management in Production and Services, 10(2), 41-56. https://doi.org/10.2478/emj-2018-0010

UN-Habitat (2016). World Cities Report 2016. Urbanization and Development e Emerging Futures. United Nations Human Settlements Programme (UNHabitat). Retrieved March 18 2020, from http://wcr.unhabitat.org/wpcontent/uploads/sites/16/2016/05/WCR-\%20Full-Report-2016.pdf

VAN DER LINDE, L.B.A., WITTE, P.A., \& SPIT, T.J.M. (2020). Quiet Acceptance vs. the 'Polder Model': Stakeholder Involvement in Strategic Urban Mobility Plans. European Planning Studies, 1-21. https://doi.org/10.1080/09654313.2020.1735310

VEGACOMP (2020). Smart City Scan of Romania. Retrieved May 18 2020, from https://vegacomp.ro/wpr/wpcontent/uploads/2020/05/e-book_smart_city_scan_of_romania_en.pdf

VIITANEN, J. \& KINGSTON, R. (2014). Smart Cities and Green Growth: Outsourcing Democratic and Environmental Resilience to the Global Technology Sector. Environment and Planning A, 46(4), 803-819. https://doi.org/10.1068/a46242

WORLD BANK GROUP (2016). World Development Indicators 2016. Retrieved April 18 2020, from http://site.ebrary.com/id/11211165 